\title{
Making room for procedural justice in restorative justice theory
}

\author{
Carolyn Hoyle and Diana Batchelor
}

\section{Introduction}

Research seeking to understand how restorative justice might reduce reoffending, or satisfy victims, suggests that it can increase participants' sense of procedural justice (Dignan, 2004). By that, we mean it can make them feel they have some control over the process, their opinions are valued, they have been respected and dealt with fairly (see, e.g. Aertsen, Bolívar, De Mesmaecker \& Lauwers, 2011; Shapland et al., 2007; Shapland, Robinson \& Sorsby, 2011; Strang, 2002; Wemmers \& Cyr, 2004; Wemmers \& Van Camp, 2011). Despite this theoretical interrelatedness or affinity between restorative justice and procedural justice, the two bodies of literature have developed quite independently of one another, arguably to the disadvantage of both. While a few restorative justice scholars have referred to procedural justice in passing, ${ }^{1}$ the relationship between the two has rarely been examined empirically.

The academic literature is awash with definitions of restorative justice, some focusing on theory, others on practice, but none consider restorative justice as explicitly aimed at delivering a procedurally just and fair way of responding to crimes or disputes. Some empirical studies draw on procedural justice theory to consider the efficacy of restorative interventions, but more difficult questions about its role in the process are rarely asked. Is procedural justice perhaps a mechanism by which restorative justice 'works'? If so, what relative weight does it have in comparison to other mechanisms? Does it play an equal role for both offenders and victims? What meaning does it have for community representatives in the restorative justice process? Should we deem a restorative justice process that doesn't increase participants' sense of procedural justice a failure?

We know much about the role procedural justice plays in enhancing the legitimacy of justice institutions, and compliance with the law, particularly from the work of Tom Tyler. Yet this knowledge has rarely been applied to improving our understanding of restorative justice processes or outcomes, despite the interest of scholars and justice institutions alike in the possible deterrent effect of restor-

* Carolyn Hoyle is Professor of Criminology, University of Oxford (UK). Diana Batchelor is a DPhil candidate, Centre for Criminology, University of Oxford (UK). Contact author: carolyn.hoyle@crim.ox.ac.uk.

1 An early study by Peachy (1986) explored the links between restorative justice and procedural justice, and Braithwaite (1999) considered this further in his long essay reviewing the literature almost twenty years ago. 
ative interventions. Tyler (2006) has suggested that there are similarities between the procedural justice model, the restorative justice model and the study of moral development. Putting aside, for our purposes here, consideration of moral development, his approach to restorative justice is too narrow to take us very far, focused on mechanisms for encouraging offenders' compliance with the law:

[The] restorative justice argument mirrors the concern in procedural justice research with developing informal and formal legal procedures that have the effect of strengthening the influence of social values on people's law-related behavior. (Tyler, 2006: 316)

He has little or nothing to say about other participants in the process, not least the victim. Furthermore, he concedes that although these approaches have some commonality, no study has attempted to compare the psychological mechanisms underlying these models or to show why and how they can be effective, or which is more efficacious.

Miller and Hefner's (2015) research is one rare example of this approach, as they do consider whether restorative justice can enhance victims' and offenders' views of procedural justice following violent crime. They found that restorative justice programmes in Australia and the United States, used for serious offences, could correct the harms caused by the criminal justice system and enhance procedural justice for both victims and offenders. Suggesting clear compatibility between these two approaches, they conclude:

By creating circumstances that enable victims and offenders to be more supportive of law and justice, [restorative justice] programs can play a key role in fostering greater system accountability and procedural justice. (Miller \& Hefner, 2015: 164)

De Mesmaecker (2014) also offers a unique perspective on the role of procedural justice in participants' perceptions of criminal justice. She conducts the kind of study we are advocating here, exploring the precise nature of the relationship between procedural justice and restorative justice. For example, she finds that victims and offenders describe procedural justice as important to them both before and after the restorative justice process. In contrast to predictions, the presence of a fair process does not seem to cushion against the impact of an unfair outcome. This takes us a step forward in understanding the nuanced role played by procedural justice, and additionally indicates that the complex relationship between procedural and restorative justice deserves further consideration.

In the procedural justice literature, little attention has been paid to how to develop and deliver procedural justice, despite the large evidence base for its benefits (Van Craen \& Skogan, 2017). Much of the restorative justice literature is devoted precisely to the implementation of schemes that empower participants, treat them with respect and give them a voice, and thus it could, in turn, contribute to our understanding of how to cultivate procedural justice. While the proce- 
dural justice model typically focuses on everyday rule following, and on common interactions between the police and the public, and restorative justice tends to be used in response to specific rule infractions, both rely on perceptions of authority figures behaving fairly and legitimately and therefore have the potential to inform each other. In arguing that scholars from both camps should look for synergies, our focus here is on justice processes involving the police, but first we pause briefly to describe what is meant by procedural justice.

\section{The promise of procedural justice}

Most definitions of procedural justice draw on the work of Tom Tyler, who expanded Thibaut and Walker's (1975) earlier definition, which focused on whether people feel they have agency within a process. Tyler (1989) found that neutrality, trust, and social standing also influenced people's judgements about procedural justice. Tyler's work had a significant effect on the path of criminological studies, which had until then been preoccupied with instrumental or outcomefocused attempts to reduce crime, such as through sentencing policy or practice. Improving compliance with the law through procedural justice - as the name suggests - means making the process fair. This, of course, is a good in itself, as well as holding the promise of instrumental effects.

There is evidence that procedural justice is associated with a perceived legitimacy of justice institutions, such as the police and courts, and that this is, in turn, associated with compliance with the law (Tyler \& Huo, 2002). Bottoms and Tankebe (2012) note that the benefits of procedural justice also extend beyond generating compliance - a functioning and fair society is maintained by an ongoing 'dialogue' between institutions and their audiences. The evidence base for factors influencing procedural justice and the mechanisms by which it leads to perceptions of legitimacy is ever growing. For example, in addition to the qualities mentioned above, people also judge the legitimacy of institutions by the extent to which their authority is bounded; that is, that the institution operates only within agreed limits to its authority (Trinkner, Jackson \& Tyler, 2018). One mechanism by which procedural justice leads to perceptions of legitimacy is through increasing a sense of social inclusion (Bradford, 2014; Bradford, Murphy \& Jackson, 2014). Social inclusion also moderates the extent to which procedural justice leads to perceptions of legitimacy; that is, the relationship between procedural justice and perceived legitimacy is even stronger for people who already feel excluded (Murphy, Cherney \& Teston, 2018).

Scholarship on restorative justice and procedural justice is not entirely discrete, as it is common to evaluate the success of restorative processes through measures of procedural justice, even though these are not explicitly described as such. However, there is clearly an opportunity for the two bodies of literature to learn from one another, and here, we consider three possible opportunities: policing policies and practices, 'non-participatory' restorative justice, and responses to wrongful convictions. 


\section{Policing policies and practices}

Procedural justice is already influencing policing policies and practice in the United Kingdom, given the evidence that it generates compliance with the law in ways that the perceived risk of sanctions does not (e.g. Hough, Jackson, Bradford, Myhill \& Quinton, 2010). However, even where a police force is persuaded that policing is better delivered within a procedural justice model, it is not clear how this is best achieved. Van Craen and Skogan (2017) find that developing procedural justice within the institution is one way to improve the public's experience of justice. The literature on restorative justice provides another: enabling dialogue between victims and offenders creates opportunities for victims to feel empowered, respected, and to have a voice.

Perhaps more importantly, where the police are already delivering restorative justice, the procedural justice literature would help us to better understand how it should be delivered. The current standards set out by the Association of Chief Police Officers of England and Wales dictate that restorative justice should involve the victim where possible, allow participants to talk about the impact of the crime, and agree on reparation (Shewan, 2011). What the standards do not set out is how any of this should be achieved, and, in reality, such procedures may end up far from 'restorative' in nature (Weisberg, 2003).

If the police were to put in place the evidence-based aims of procedural justice, this could result in more effective processes. Labels aside, officers should aim to give all parties in a dispute a voice, make them feel respected and that they have been treated fairly. Restorative justice advocates might argue that this is how restorative justice should be done because these are its core principles, or that it is simply a matter of doing it properly. But this argument holds little water for busy police officers and their line managers who must choose where to allocate limited resources. Much more convincing, however, is the evidence from the procedural justice literature that such an approach can increase compliance and cooperation with justice institutions in a variety of contexts. This, if integrated into the restorative justice scholarship, might persuade police services of the benefits of delivering justice restoratively, though we would not wish them to focus on fair processes only as a means to an end.

\section{Procedural justice and 'non-participatory' restorative justice}

The elephant in the room in most discussions about restorative justice is the experience of participants who are either unable or unwilling to participate in restorative justice. Restorative justice is sold on the premise that the main parties to a dispute meet, or at least indirectly communicate with one another. They then have the opportunity to tell the others how they experienced the offence, what they were thinking, or feeling, at the time, and how they have been since then. It is the sharing of experiences that is key to reparation and reintegration. In some countries, such as Norway and Belgium, restorative justice is widely used and take-up rates are high. This is not the norm, however, and in other jurisdictions, 
relatively few referrals are made to restorative justice, and communication between victims and offenders is much rarer, for example, in England and Portugal (Dünkel, Grzywa-Holten \& Horsfield, 2015).

There are multiple hurdles en route to a meeting between a victim and an offender, and it is common for one participant to be interested in restorative justice but unable to gain access to a restorative process. Sometimes barriers occur at the referral stage, or are raised by criminal justice professionals (Laxminarayan, 2014), sometimes participants do not receive the information they need (Bolívar, Aertsen \& Vanfraechem, 2009), there may be logistical hurdles or the other party simply does not want to participate (Shapland et al., 2006). In particular the majority of police-led restorative interventions in the United Kingdom proceed without victim participation, making it less likely that they will receive therapeutic or material benefits from the process, and that offenders will experience reintegrative gestures, even if both engage in 'shuttle mediation' (Hoyle, 2002). Furthermore, some police practices labelled 'restorative justice', especially swift 'street' disposals, seem to be anything but restorative, providing little for victims (Marder, 2018).

While in some countries restorative justice meetings are conducted on the condition that the victim is present (Bolivar et al., 2009), in the United Kingdom, and elsewhere, this has not been the case. Hoyle (2002) interviewed victims who had decided against participating in restorative conferences. The conflict between good preparation and organisational constraints, and the difficulties officers experienced in explaining to victims the potential of restorative justice without coercing them, could be helped by more procedurally just encounters with victims. Procedural techniques, to reform organisational culture and empower victims, might help the police to better manage the inevitable tension between doing what the facilitator thinks is right and giving potential participants the information and time to make informed choices. Again, here the procedural justice literature would provide an important resource for restorative justice scholars and practitioners. Nonetheless, some victims will choose not to meet 'their' offenders, whether for their own practical reasons, because they are afraid of retaliation or because they do not see the point (Hoyle, 2002); in such cases, procedural justice might help them to get more out of non-participatory processes.

In Hoyle's study, some victims engaged in other 'indirect' forms of participation including 'shuttle mediation' (where the facilitator acts as a go-between to enable the main parties to express their feelings and even to establish reparation agreements). However, while participants may experience benefits from such 'non-participatory' restorative justice, the benefits are not as clear as when the parties communicate directly with one another (Hoyle, 2002). It is important to ascertain how these benefits of direct participation occur, in order to improve practice. Victims and offenders may experience a sense of process control, even when they do not meet one another. Wemmers and Cyr (2004) found that victims wanted to have 'process control', which they describe as input into the decisionmaking process; but, in general, victims did not want 'decision control'. Victims in non-participatory restorative responses, therefore, may not mind that the final 
decision - for example, regarding reparation - is out of their hands, as long as they feel they have had some input into the process and been listened to.

Many victims say their motivation for taking part in restorative justice encounters is to have their say, by which they usually mean a chance to tell the offender about the impact of the crime (Hoyle, 2002). In procedural justice terms, having a 'voice' is an important determinant of satisfaction with justice proceedings. Where a victim will not get to tell his or her story directly to the offender, this need to communicate may nevertheless be satisfied in other ways. If victims feel that the facilitator is a legitimate representative of the justice system, for example, talking to the facilitator about the crime and its impact may satisfy this need. Furthermore, sometimes facilitators can identify a victim's or offender's need for voice elsewhere; for example, within their family. This can be facilitated even in the absence of a conference, and perhaps a focus on this within the restorative justice literature could improve the experiences of participants who do not have the opportunity - or are unwilling - to participate in a conference.

Procedural justice highlights the importance of a process being fair, and in the case of restorative justice, this often means the involvement of a neutral facilitator. When the parties will not meet, it could be tempting for facilitators to abandon neutrality and assume the role of supporter, particularly of the victim, though perhaps also of a young and apparently vulnerable offender where an adult victim has refused to meet. The procedural justice literature tells us that this is a bad idea, because participants are most likely to trust the process when it is fair, and impartiality is typically experienced as fair even when one party feels they have a legitimate grievance. This may be especially true when victims and offenders can identify with each other. Hough et al. (2010) point out that many victims are also offenders and vice versa, so this could be one reason that people are reassured by institutions that treat both fairly.

As we have seen, applying a procedural justice framework to 'non-participatory' restorative processes could help us understand the mechanisms by which participants can benefit from the more common restorative interventions. This could help to bring about three achievements: 1) Create a set of minimum standards for restorative responses. This has traditionally been hard because of the changing context and nature of restorative practices, and because the outcomes for different participants can vary greatly. The implementation of process standards according to the evidence base on procedural justice is, therefore, one potential way to ensure that service users gain the maximum possible benefits from restorative justice. 2) Enable potential participants to make an informed choice about participation. When victims and offenders agree to participate in restorative processes, they often know little about what the process will involve - because the form it takes depends so much on the wishes of the participants. A procedural justice framework could provide a better description of what is promised by way of process delivery (the minimum standard just described), clearly distinct from outcomes that may or may not be achieved. This would enable victims and offenders to make better-informed decisions about participation and have reasonable expectations of the process. 3) Improve practice. The long list of lofty goals of restorative justice can detract from good practice. In the hope of creating a trans- 
formative process that prevents reoffending and eliminates trauma symptoms, police facilitators may try to be all things to all people - police officer, probation manager, mentor, and therapist. Perhaps the focus should be on making the process just, and letting the other potential outcomes take care of themselves.

\section{Restorative and procedural justice in response to wrongful convictions}

Finally, we reflect on the promise of restorative justice in responding to cases where those who are wrongfully convicted have been the victims of police misconduct; cases where there are significant and inherent power imbalances.

While the wrongfully convicted experience similar injuries to crime victims (Hoyle, 2016), their trauma often results, at least in part, from misconduct or incompetence by state officials - police or prosecutors - who breach procedural safeguards and sometimes engage in malfeasance (Gould \& Leo, 2010). As such, wrongful convictions are arguably state harms that could be repaired through restorative processes that enable the state to make amends (Hoyle, 2016). Justice and redress for harms done is a critical part of 'ordinary' victims' recovery (Boom \& Kuijpers, 2012) and the literature suggests that victims of wrongful conviction also want the state, and criminal justice officials in particular, to take responsibility for the errors that have occurred. Without this, there remains a 'profound cynicism and mistrust regarding the fairness and legitimacy of authority figures' (Campbell \& Denov, 2004: 155).

It seems to us that where police, in particular, have responded to crimes in ways that breach the procedural safeguards of suspects much earlier in the process, they have a moral obligation to consider procedurally just ways of repairing the harms done by their own, and their colleagues' behaviour. Restorative encounters, if handled with care, could restore the legitimacy of agencies whose reputations were damaged following a wrongful conviction, and rehabilitate and re-educate criminal justice personnel who erred or engaged in malpractice, thus potentially reducing the risk of further wrongful convictions. Such restorative encounters must, however, be informed by procedural justice theory to help to mitigate the power imbalance, and to realise the potential of such encounters to make police generally more procedurally fair and just.

When treated with respect and given a voice that has for too long been silenced and disbelieved, the wrongfully convicted might be able to let go of some of the anger and regret about his or her past treatment and be therefore better able to make use of what social capital they have left in order to rebuild their damaged lives and communities. The police, in turn, by being forced to scrutinise their own behaviour in a non-punitive forum will be more likely to take personal as well as institutional responsibility for their failings in the past and for preventing similar situations in the future, in what Tyler (2003) has referred to as a 'process-based model of regulation'.

A procedural justice informed model of restorative justice for the wrongfully convicted could motivate self-regulatory behaviour on the part of the police but also, perhaps, on the part of the wrongfully convicted, many of whom struggle 
with self-control and self-motivation for some time following release from prison (Hoyle \& Tilt, 2018). A restorative response by a police service - that actively reflects feelings of responsibility for the harms done - and a commitment to addressing flaws in the criminal process, has the potential to return to the wrongfully convicted belief in the legitimacy of the police as an institution, legitimacy that is damaged by wrongful convictions.

The research conducted by Miller and Hefner (2015) - on restorative justice delivered post conviction - suggests that for victims who did not feel they received procedural justice from the formal criminal justice system at trial and sentencing, restorative processes can restore their sense of balance and provide some relief by allowing direct participation to facilitate healing. Furthermore, offenders - in our example here, the police - who participate in a process that treats them with dignity and respect, and who learn how their past behaviour has harmed others, may develop respect for the law, increasing compliance with the law in future. While it is unusual to think of police officers needing to comply with the law, the evidence from the literature on wrongful convictions, as well as on policing more generally, demonstrates that the police too often break or circumvent the law or their own procedural rules in their day-to-day responses to crimes (Hoyle \& Sato, 2018).

Similarly, restorative practices aimed at enhancing procedurally just policing in jurisdictions with considerable conflict between certain communities and the police, and where there is a clear legitimacy deficit within the police may well reap benefits. Restorative justice programmes 'present the opportunity to redress processual wrongs in a fair and effective way' (Miller \& Hefner, 2015: 163-164). How to approach, to motivate and to include the police in a process of dialogue in countries with significant structural police violence, such as Brazil, of course remains a challenge.

We have focused here on the police, given that in common law systems police and prosecutorial misconduct contributes to many wrongful convictions. However, in continental systems, other judicial actors, not least judges, have their part to play and could be included in restorative interventions aimed at making good the damage done to the wrongfully convicted person and at systemic learning and enhancement of procedural justice mechanisms to reduce future errors of justice as well as unjust behaviours.

\section{Conclusion}

Maruna (2016: 289-290) sees restorative justice as 'primarily a normative theory of justice - an argument for what should be done in the wake of actions that have caused harm ...'. We concur, but suggest that a normative approach to restorative justice should be informed by procedural justice theory. There is a strong normative argument for restorative processes to coexist alongside criminal justice processes for reasons related to the procedural safeguards that should come with a statutory justice response. We should be concerned with how restorative approaches can provide much-needed improvements to the criminal process as 
well as to victims, offenders and wider communities. We have suggested here that procedural justice theory and the empirical work that has further developed that theory, provides mechanisms for doing just that. Procedural justice could inform restorative justice theory and practice, making it more likely to be fair and legitimate and thereby produce positive outcomes, though our main interest here is on fairness of process, rather than any future impact that might have.

One of the main benefits of restorative conferences - particularly those that include supporters of the victims and offenders - is the provision of social capital for those parties most affected by the offence (the victim and the offender). The wise words of a facilitator or the pleas of others not to reoffend are not likely to have as great an impact on an offender as the offer of friendship, support and even informal mentoring, not to mention useful employment. Similarly, victims are most likely to feel relieved, and experience less fear and anger following a conference, when they have available to them support from relevant others throughout the process and beyond. This support, however, relies on all parties believing the process to be procedurally just. We suggest that many facilitators - from police, probation and even voluntary organisations - currently either do not know what procedurally just processes should look like or how to secure them. If restorative justice scholars were to work with procedural justice scholars, these processes may be better informed and more efficacious. As Shapland (2017: 4) has argued, at present, 'we simply [do] not have the detailed knowledge of current restorative justice processes to be able to say what processes were found more helpful for which participants'. For example, the restorative justice literature - particularly that focused on police facilitation - emphasises the importance of community involvement (see, e.g. Bazemore \& Griffiths, 2003), but provides little theoretical guidance on how community involvement can be nurtured safely and restoratively. A procedurally just restorative approach would have the potential to guard against or respond effectively to non-restorative practices preceding, during or following conferences, such as exclusionary practices by the community (Cunneen \& Hoyle, 2010).

So far, we have focused on learning from procedural justice theory, but there are also ways that procedural justice can learn from restorative justice. In aspiring for more compliance with the law, procedural justice theory, and indeed most police reform practices that have developed from it, focuses on increasing legitimacy in individual police-citizen interactions. There is less attention to the wider communities in which individuals belong. As recent work by Monica Bell (2017) makes clear, this is insufficient. She draws on empirical data with young African Americans to show that communities who distrust the police nonetheless often comply with the law and respect it. While many have had no interactions with the police, they do not trust them as they know people who have had bad experiences. Indeed, Bell argues that in such cases widespread community distrust is not really about non-compliance with the law. For her, the focus needs to be on the causes of, and solutions for, community 'legal estrangement', rather than simply focusing on individuals. Among possible solutions, she recommends 'democratising the police' and more 'deliberative participation' in policing, both of which could be 
delivered within a model of restorative community policing, which has long valued deliberative and democratic accountability (Roche, 2003).

The main model of restorative justice assumes participation by victims, offenders and a wider community. While this is often translated by police facilitators as a 'community of care' - involving friends and family members - it can be, and sometimes is, a geographical community or an identity community, or a community similarly harmed by the offence or similar offences (e.g. hate crimes; Walters \& Hoyle, 2011). Hence, in light of Bell's critique of the individuality of procedural justice approaches, we see that procedural justice theory may have much to learn from restorative justice.

\section{References}

Aertsen, I., Bolívar, D., De Mesmaecker, V. \& Lauwers, N. (2011). Restorative justice and the active victim: Exploring the concept of empowerment. Temida, 14(1), 5-19.

Bazemore, G. \& Griffiths, C. (2003). Police reform, restorative justice and restorative policing. Police Practice and Research, 4(4), 335-346.

Bell, M.C. (2017). Police reform and the dismantling of legal estrangement. Yale Law Journal, 126(7), 2054-2150.

Boom, A. ten \& Kuijpers, K.F. (2012). Victims' needs as basic human needs. International Review of Victimology, 18(2), 155-179.

Bolívar, D., Aertsen, I. \& Vanfraechem, I. (2009). Victims and restorative justice: Country reports. European Commission project JUST/2009/JPEN/AG/0628. Leuven: European Forum for Restorative Justice.

Bottoms, A. \& Tankebe, J. (2012). Beyond procedural justice: a dialogic approach to legitimacy in criminal justice. Journal of Criminal Law \& Criminology, 102(1), 119-170.

Bradford, B. (2014). Policing and social identity: procedural justice, inclusion and cooperation between police and public. Policing and Society, 24(1), 22-43.

Bradford, B., Murphy, K. \& Jackson, J. (2014). Officers as mirrors. British Journal of Criminology, 54(4), 527-550.

Braithwaite, J. (1999). Restorative justice: assessing optimistic and pessimistic accounts. In M. Tonry (ed.), Crime and justice: A review of research (vol. 25, 1-127). Chicago: University of Chicago Press.

Campbell, K. \& Denov, M. (2004). The burden of innocence: Coping with a wrongful imprisonment. Canadian Journal of Criminology and Criminal Justice, 46, 139-164.

Cunneen, C. \& Hoyle, C. (2010). Debating restorative justice. Oxford: Hart Publishing.

De Mesmaecker, V. (2014). Perceptions of justice. London: Routledge.

Dignan, J. (2004). Understanding victims and restorative justice. Maidenhead: McGraw-Hill Education.

Dünkel, F., Grzywa-Holten, J. \& Horsfield, P. (eds.). (2015). Restorative justice and mediation in penal matters - A stocktaking of legal issues, implementation strategies and outcomes in 36 European countries. Mönchengladbach: Forum Verlag Godesberg.

Gould, J.B. \& Leo, R.A. (2010). One hundred years later: wrongful convictions after a century of research. Journal of Criminal Law and Criminology, 100(3), 825-868.

Hough, M., Jackson, J., Bradford, B., Myhill, A. \& Quinton, P. (2010). Procedural justice, trust, and institutional legitimacy. Policing, 4(3), 203-210.

Hoyle, C. (2002). Securing restorative justice for the non-participating victims. In C. Hoyle \& R. Young (eds.), New visions of crime victims (pp. 97-131). Oxford: Hart Publishing. 
Hoyle, C. (2016). Victims of the state: recognizing the harms caused by wrongful convictions. In M. Bosworth, C. Hoyle \& L. Zedner (eds.), Contours of criminal justice (pp. 270-288). Oxford: Oxford University Press.

Hoyle, C. \& Sato, M. (2018, forthcoming). Last chance for justice: wrongful convictions and the Criminal Cases Review Commission. Oxford: Oxford University Press.

Hoyle, C. \& Tilt, L. (2018, forthcoming). The Benefits of Social Capital for the Wrongfully Convicted: Considering the promise of a resettlement model. [under review]

Laxminarayan, M. (2014). Accessibility and initiation of restorative justice. Leuven: European Forum for Restorative Justice.

Marder, I. (2018). Restorative justice and the police: exploring the institutionalisation of restorative justice in two English forces. (Unpublished PhD Thesis). University of Leeds, UK. Retrieved from: http://etheses.whiterose.ac.uk/19578/(last accessed 1 May 2018).

Maruna, S. (2016). Desistance and restorative justice: it's now or never. Restorative Justice: an International Journal, 4(3), 289-301.

Miller, S.L. \& Hefner, M.K. (2015). Procedural justice for victims and offenders?: exploring restorative justice processes in Australia and the US. Justice Quarterly, 32(1), 142-167.

Murphy, K., Cherney, A. \& Teston, M. (2018). Promoting Muslims' willingness to report terror threats to police: testing competing theories of procedural justice. Justice Quarterly, 8825, 1-26.

Peachy, D.E. (1986). Restorative justice in criminal conflict: victims' and observers' perspectives. (Unpublished PhD Dissertation). University of Waterloo, UK.

Roche, D. (2003). Accountability in restorative justice. Oxford: Oxford University Press.

Shapland, J. (2017). In search of a research nirvana: what process for whom? Restorative Justice: an International Journal, 5(1), 1-6.

Shapland, J., Atkinson, A., Atkinson, H., Chapman, B., Colledge, E., Dignan, J., Howes, M., Johnstone, J., Robinson, G. \& Sorsby, A. (2006). Restorative justice in practice: the second report from the evaluation of three schemes. Sheffield: Centre for Criminological Research.

Shapland, J., Atkinson, A., Atkinson, H., Chapman, B., Dignan, J., Howes, M., Howes, M., Johnstone, J., Robinson, G. \& Sorsby, A. (2007). Restorative justice: the views of victims and offenders. The third report from the evaluation of three schemes. London: Ministry of Justice Research Series 3/07.

Shapland, J., Robinson, G. \& Sorsby, A. (2011). Restorative justice in practice: evaluating what works for victims and offenders. London: Routledge.

Shewan, G. (2011). ACPO restorative justice guidance and minimum standards. London: Association of Chief Police Officers of England, Wales \& Northern Ireland.

Strang, H. (2002). Repair or revenge. Victims and restorative justice. Oxford: Oxford University Press.

Thibaut, J.W. \& Walker, L. (1975). Procedural justice: a psychological analysis. Hillsdale: Lawrence Erlbaum Associates.

Trinkner, R.J., Jackson, J. \& Tyler, T.R. (2018). Expanding 'appropriate' police behavior beyond procedural justice: bounded authority and legal legitimation. SocArXiv: Open Archive in Social Science. doi:10.17605/OSF.IO/NEZM6.

Tyler, T.R. (1989). The psychology of procedural justice: a test of the group-value model. Journal of Personality and Social Psychology, 57(5), 830-838.

Tyler, T.R. (2006). Restorative justice and procedural justice: dealing with rule breaking. Journal of Social Issues, 62(2), 307-326.

Tyler, T.R. \& Huo, Y.J. (2002). Trust in the Law: encouraging public cooperation with the police and courts. New York: Russell-Sage. 
Van Craen, M. \& Skogan, W.G. (2017). Achieving fairness in policing: the link between internal and external procedural justice. Police Quarterly, 20(1), 3-23.

Walters, M.A. \& Hoyle, C. (2011). Exploring the everyday world of hate victimization through community mediation. International Review of Victimology, 18(1), 7-24.

Weisberg, R. (2003). Restorative justice and the danger of community. Utah Law Review, 1 , 343-374. doi:10.2139/ssrn.373483.

Wemmers, J.-A. \& Cyr, K. (2004). Victims' perspectives on restorative justice: how much involvement are victims looking for? International Review of Victimology, 11, 259-274.

Wemmers, J.-A. \& Van Camp, T. (2011, June). The offer of restorative justice to victims of violent crime: Should it be protective or proactive? CICC Résultats de recherche, No. 4. Montreal: University of Montreal. 